\title{
Stress responses of tomato protoplasts to copper and paraquat
}

\author{
Antoni Rueda ${ }^{1}$, Mauricio Rojas ${ }^{1}$, Mario Lobo ${ }^{2}$, Aura Urrea ${ }^{1}$, Catalina Restrepo ${ }^{1}$, Catalina Botero ${ }^{1} \&$ Carlos \\ Pelaez $^{1}$
}

${ }^{1}$ Universidad de Antioquia, Medellín - Colombia, Colombia; ${ }^{2}$ Corpoica, Vía Las Palmas, Rionegro Antioquia, Colombia

Author for correspondence: Carlos Pelaez, e-mail: cpelaez@matematicas.udea.edu.co

\begin{abstract}
Plants are often exposed to external biotic or abiotic agents that can damage cells. Biotic agents include molecules produced by pathogens, and abiotic agents include ultraviolet radiation, heavy metals and xenobiotic agents such as herbicides. Because of the importance of abiotic stresses and the limited knowledge of the defense responses of plants to stresses, a study was conducted using flow cytometry to evaluate endocellular events in protoplasts of two tomato species, Lycopersicon hirsutum and Lycopersicon esculentum, following exposure to $10 \mathrm{mM} \mathrm{CuCl}_{2}$ and $1 \%$ paraquat. During the first $30 \mathrm{~min}$ of exposure to $10 \mathrm{mM} \mathrm{CuCl}_{2}$, mean fluorescence intensity values in both species decreased by more than 50\% compared to the untreated control. During the first 30 min of paraquat treatment, the production of reactive oxygen species, evaluated as the incidence of protoplasts in which the superoxide anion was present, was $32.9 \%$ and $25.4 \%$, respectively, for L. hirsutum and L. esculentum. Hyperpolarization of the mitochondria for both tomatoes species was observed during the first $2 \mathrm{~h}$. The absence of early membrane damage and the markedly detrimental effects of the treatments on the mitochondria suggest that additional mechanisms which lead to cell death may be involved in these processes, and that these mechanisms may be associated with apoptosis.
\end{abstract}

Key words: Lycopersicon, abiotic elicitation, apoptosis, programmed cell death.

\section{RESUMO}

Respostas dos protoplastos do tomate ao estresse gerado pelo cobre e o paraquat

As plantas estão expostas a agentes externos bióticos e abióticos que podem produzir dano nas celulas. Os agentes bióticos incluem moléculas produzidas por patógenos e os agentes abióticos incluem radiação ultravioleta, metais pesados e os agentes xenobióticos como os herbicidas. Devido à importancia do estresse abiotico e o limitado conhecimiento sob as respostas de defensa das plantas ao estresse, este estudo foi feito usando a citometría de fluxo para avaliar os eventos endocelulares de duas espécies de tomate: Lycopersicon hirsutum e Lycopersicon esculentum depois da exposição a $10 \mathrm{mM} \mathrm{CuCl}_{2}$ e $1 \%$ do paraquat. Durante os primeiros 30 min da exposição ao CuCl os valores da intensidade média da fluorescência em ambas as espécies diminuiu mais do 50\% quando comparado com os controles não tratados. No caso do tratamento com o paraquat, depois dos primeiros 30 minutos a produção das espécies reativas do oxigênio, (avaliada pela presença do ânion superóxido) na espécie L. hirsutum e L. esculentum foi de 32,9\% e 25,4\%, respectivamente. A hiperpolarização das mitocôndrias das duas espécies do tomate foi observada durante as 2 primeiras horas. A ausência de dano no início ao nível da membrana e os efeitos adversos na mitocôndria causados pelos tratamentos sugerem que poda haver mecanismos adicionais que levam à morte celular, e que estes mecanismos podem estar associados à apoptose.

Palavras-chave: Lycopersicon, apoptose, eliciação abiótica, morte celular programada.

\section{INTRODUCTION}

Previous literature has reported that exposure of plants to heavy metals (Mithofer et al., 2004; Yakimova et al., 2007) and xenobiotics causes stress and cell death in plants (Álvarez \& Espinosa, 2004). The hypersensitivity response (HR) is a frequently described plant defense reaction and has been considered as a type of suicide of cells surrounding the site of pathogen attack, thus preventing a subsequent

Abbreviations used: HR, hypersensitivity response; MFI, mean fluorescence intensity; PCD, programmed cell death; ROS, reactive oxygen species. invasion of biotrophic pathogens and obligate parasites such as viruses (Lamb \& Dixon, 1997; Pennell \& Lamb, 1997; Lam et al., 1999; Zhang et al., 2004; Hofius, 2007). In recent years, interest in the HR mechanism has increased among plant researchers because it shares similarities with apoptosis in animals (Danon et al., 2000; Hofius, 2007). Apoptosis occurs in animal cell populations in various states of embryonic development and is seen in diverse pathologies as a response to environmental stress (Godbole et al., 2003). It has been proven that different forms of stress can lead to cell death, and although differences in this process are known among plant and animal cells, there are also many similarities, suggesting that a large portion of the genetic characteristics and biochemical responses responsible for 
this process in plants have been evolutionarily conserved (Godbole et al., 2003; Van Doorn, 2005).

As an abiotic stress factor in plants, copper was reported to cause oxidative stress, beginning with the interruption of electron transport in the photosystems, and resulting in irreversible damage to the cell (Hsu et al., 1988; Narendranath et al., 1989; Yruela et al., 1996; Ke Shi-sheng, 2007). Evaluated based on the presence of superoxide anion, Paraquat, a herbicide whose active molecule is a bybiridyl with two quaternary nitrogen molecules, is a xenobiotic stress factor that interrupts electron flow in photosystem I. Paraquat inhibits passage of electrons to ferredoxin so that the electrons are given up to oxygen in an unpaired manner by a series of oxidationreduction reactions and as a consequence reactive oxygen species (ROS) are produced (Karp, 2006; Yu et al., 2007). Paraquat is considered toxic, not only because it interrupts photosynthesis, but because the production of ROS results in lipid peroxidation and changes in the biomolecules that shape damage in the membranes (Yu et al., 2007). Several studies reported the significance of ROS in oxidative stress, signal transduction and plant defense (Breusegem et al., 2001; Apel \& Hirt, 2004; Torres \& Dangl, 2005). Although the described mechanisms by which copper and paraquat cause plant stress have been generally accepted, the present study suggests that additional pathways contribute to stress and cell death and thus may be associated with apoptosis.

Evidence in animal models supports the significance of mitochondrial signaling during cell apoptosis (Lin et al., 2006). Several studies indicate that the uncoupling of electron transport by a specific elicitor, leading to decreased ATP production, causes a decrease in the mitochondrial membrane potential, and a decrease in ROS production (Lin et al., 2006). In the present study, the protoplasts of two tomato species were exposed to copper and paraquat and evaluated by flow cytometry for the production of ROS, and damage to the cell membranes and mitochondria to determine whether or not the changes are associated with apoptosis.

\section{MATERIALS AND METHODS}

Two tomato species were used: Lycopersicon hirsutum, (PI 251305 accession), which was reported to be resistant to phytopathogens (Vallejo, 1999) and Lycopersicon esculentum, (L-507 accession) variety Licato (cultivable species). These plants were obtained from the System of Vegetable Germoplasm Banks of Colombia under the Colombian Agricultural Research Corporation CORPOICA.

\section{Material Regeneration and Propagation}

The tomato materials were stored seeds, which were planted in sterile Murashige and Skoog nutrient medium (Sigma Aldrich), at a ratio of $4.4 \mathrm{~g} \mathrm{~L}^{-1}$ medium, $1.7 \mathrm{mg} \mathrm{L}^{-1}$ gelling agent (phytagel) and $30 \mathrm{~g} \mathrm{~L}^{-1}$ of sucrose. To prepare the medium, the salts and sucrose were dissolved in sterile distilled water by boiling, dispensed in $15 \mathrm{~mL}$ per bottle, allowed to cool, and autoclaved for $15 \mathrm{~min}$ at $120^{\circ} \mathrm{C}$ at 220.5 PSI.

\section{Protoplast preparation}

To obtain protoplasts, mesophyll tissue was cut from leaves produced from the germinated seeds, and two hundred milligrams of the mesophyll tissue were pre-plasmolized in the dark for one hour at $25^{\circ} \mathrm{C}$ in 20 $\mathrm{mL}$ of CPW salts $(1.0 \mathrm{mM} \mathrm{NaCl}, 0.2 \mathrm{mM} \mathrm{KCl}$ and 0.2 $\left.\mathrm{mM} \mathrm{CaSO})_{4}\right), 9 \%$ mannitol and $3 \mathrm{mM} 2$-(N-morpholino) ethanesulfonic (MES) acid, at $\mathrm{pH}$ 5.8. The plasmolizing solution was then replaced with $20 \mathrm{~mL}$ of $0.6 \%$ cellulase and $0.1 \%$ pectinase and incubated in darkness at $25^{\circ} \mathrm{C}$ for 8 $\mathrm{h}$. After the enzymatic treatment, the suspension of digested leaves was washed in $20 \mathrm{~mL}$ of a solution of CPW salts (consistent with concentrations used previously) and $20 \mathrm{~g}$ $\mathrm{L}^{-1} \mathrm{KCl}$, filtered through gauze, and centrifuged at $600 \mathrm{rpm}$ for $3 \mathrm{~min}$. Each pellet was resuspended in $10 \mathrm{~mL}$ of the washing solution and centrifuged again at $600 \mathrm{rpm}$ for 3 min. The protoplasts were then suspended in $9 \mathrm{~mL}$ of $15 \%$ of sucrose in CPW salts and $1 \mathrm{~mL}$ of the washing solution and centrifuged again for $7 \mathrm{~min}$ at $600 \mathrm{rpm}$ for microscopic observations. The protoplasts obtained were then used in flow cytometry assays (Figure 1).

\section{Evaluation of protoplast damage by flow cytometry}

Protoplast damage induced by $10 \mathrm{mM} \mathrm{CuCl}$ and $1 \%$ paraquat was evaluated by flow cytometry using EPICS XL (Coulter Electronics, Inc., Hialeah, FL). Between 6000 and 10,000 events (protoplasts) were evaluated. Readings were carried out every $15 \mathrm{~min}$ for the first $2 \mathrm{~h}$ of treatments (early events) and subsequently at 3, 24, 48 and $72 \mathrm{~h}$ (late events). In initial assays concentrations of 10,1 and $0.1 \mathrm{mM}$ $\mathrm{CuCl}_{2}$ and $1,0.2$ and $0.02 \%$ paraquat were used. To evaluate alterations in mitochondrial permeability that are associated principally with apoptosis, protoplasts in their own medium were stained with $50 \mathrm{nM}$ DiOC6. To detect plasma membrane damage, which takes place during necrosis and late apoptosis, protoplasts were stained with $0.1 \mu \mathrm{g} / \mathrm{mL}$ propidium iodide. Mitochondrial damage was defined as cell populations showing changes in the MFI of DiOC6, which depends on the differences in potentials between the mitochondrial membrane and the cytosol, causing an effect known as depolarization or hyperpolarization (Figure 2). To evaluate the production of ROS (i.e. the superoxide anion), the protoplasts with the treatments were incubated for $20 \mathrm{~min}$ in the dark at room temperature in $0.1 \mu \mathrm{g} / \mathrm{mL}$ dihydroethydine and analyzed by flow cytometry.

\section{Statistical analysis}

Linear regression analyses were performed to obtain the percentage of membrane damage, percentage of protoplast with reactive oxygen species and kinetics of the mean fluorescence intensity (MFI) of DiOC6, which 


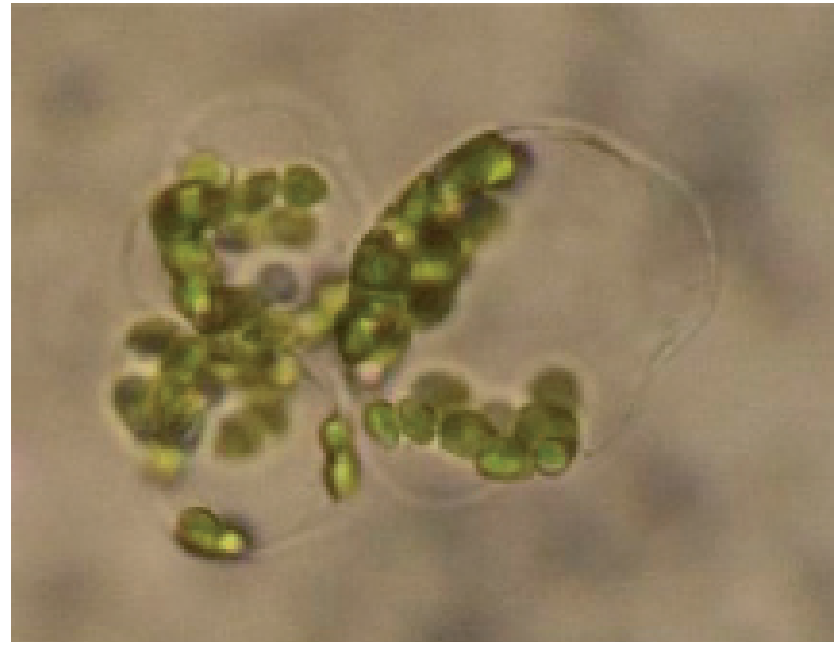

FIGURE 1 - Photograph of three protoplasts of the species Lycopersicon hirsutum.

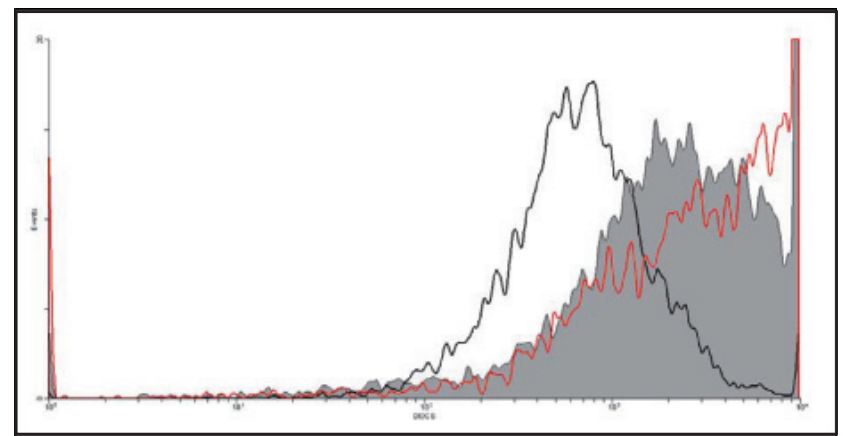

FIGURE 2 - Mean fluorescence intensity (MFI) of DiOC6 stain in protoplasts of L. hirsutum during the first fifteen minutes of treatment with $10 \mathrm{mM} \mathrm{CuCl}$ and $1 \%$ paraquat. Grey histogram (untreated control), empty histogram (treatment with copper), red histogram (treatment with paraquat).

signified either depolarization or hyperpolarization of the internal mitochondria membrane. These variables were analyzed separately during the first $2 \mathrm{~h}$ (early events) and between 3 and $72 \mathrm{~h}$ (late events). This model was used to fulfill the aim of the study, which was to determine effects of treatments on cell integrity.

\section{RESULTS}

\section{Responses of protoplasts to copper}

No increase was observed in incidence of protoplasts with membrane damage for L. hirsutum or L. esculentum during $2 \mathrm{~h}$ of exposure to $10 \mathrm{mM} \mathrm{CuCl}_{2}$. During this period, MFI values for untreated protoplasts of both tomato species were similar, but MFI values of the $\mathrm{CuCl}_{2}$-treated protoplasts decreased by more than $50 \%$. The treated protoplasts showed a decreased ability to capture DiOC6 compared to the untreated protoplasts (Figure 3, Table 1). None of the $\mathrm{CuCl}_{2}$ treatments induced the oxidation of dihydroethydine in the protoplasts of either tomato species during the first $30 \mathrm{~min}$, indicating that the mitochondria were damaged before ROS were produced. The mitochondrial responses observed during the first $2 \mathrm{~h}$ of exposure to $\mathrm{CuCl}_{2}$ specifically depolarization, continued for 3-72 $\mathrm{h}$ after the treatments in protoplasts of both tomato species (Figure 4, Table 1).

\section{Response of $L$. hirsutum and $L$. esculentum protoplasts to paraquat}

During the first $2 \mathrm{~h}$ of paraquat treatment, when measurements were made every $15 \mathrm{~min}$, an increase in the capture of DiOC6 was observed, which was interpreted as membrane hyperpolarization. The fluctuations observed in the MFI of the untreated controls were small and the linear regression models for the periods of evaluation were not significant and had near-zero slopes. In L. esculentum a similar phenomenon was observed, but hyperpolarization levels were slightly lower (Figure 5, Table 1). A sudden high production of reactive oxygen species is an important aspect of cell damage. In contrast to the copper treatment, paraquat caused significant production of ROS. During the first $30 \mathrm{~min}$ of paraquat treatment, the production of ROS, evaluated as the incidence of superoxide anion in the protoplasts, was $32.9 \%$ and $25.4 \%$, respectively for $L$. hirsutum and L. esculentum. (Table 2).

The responses of the protoplasts measured during the first $3 \mathrm{~h}$ of treatments indicated in general that the integrity of the protoplast plasma membrane was maintained for both species. During late events the membrane of $L$. hirsutum was approximately $17 \%$ damaged with a slope of 0.84 and a p-value of 0.05 , which was greater than the untreated control. L. esculentum showed a slope of 8.7, which was also greater than the untreated control (Table 3 ).

On the other hand, the hyperpolarization or depolarization of the mitochondrial membranes caused by the paraquat treatment that was observed during the period of early events continued throughout the late events. $L$. hirsutum showed a greater hyperpolarization at $3 \mathrm{~h}$, after which it behaved similarly to the untreated control. $L$. esculentum behaved similarly to L. hirsutum (Figure 6). During the late events, dihydroethydine oxidation levels were above $50 \%$ for the two species treated with paraquat, and a positive slope of 1 was observed for L. hirsutum in comparison to a negative slope for the untreated control (Table 3). Although this research did not reveal any significant regression models for L. esculentum, 49.9\% of the protoplasts exhibited ROS production, showing a slope 10 times greater than that of the untreated control (Table 3).

\section{Dose-Response Assays}

An inverse dose-response effect for the membrane damage variable was observed in both species because the 

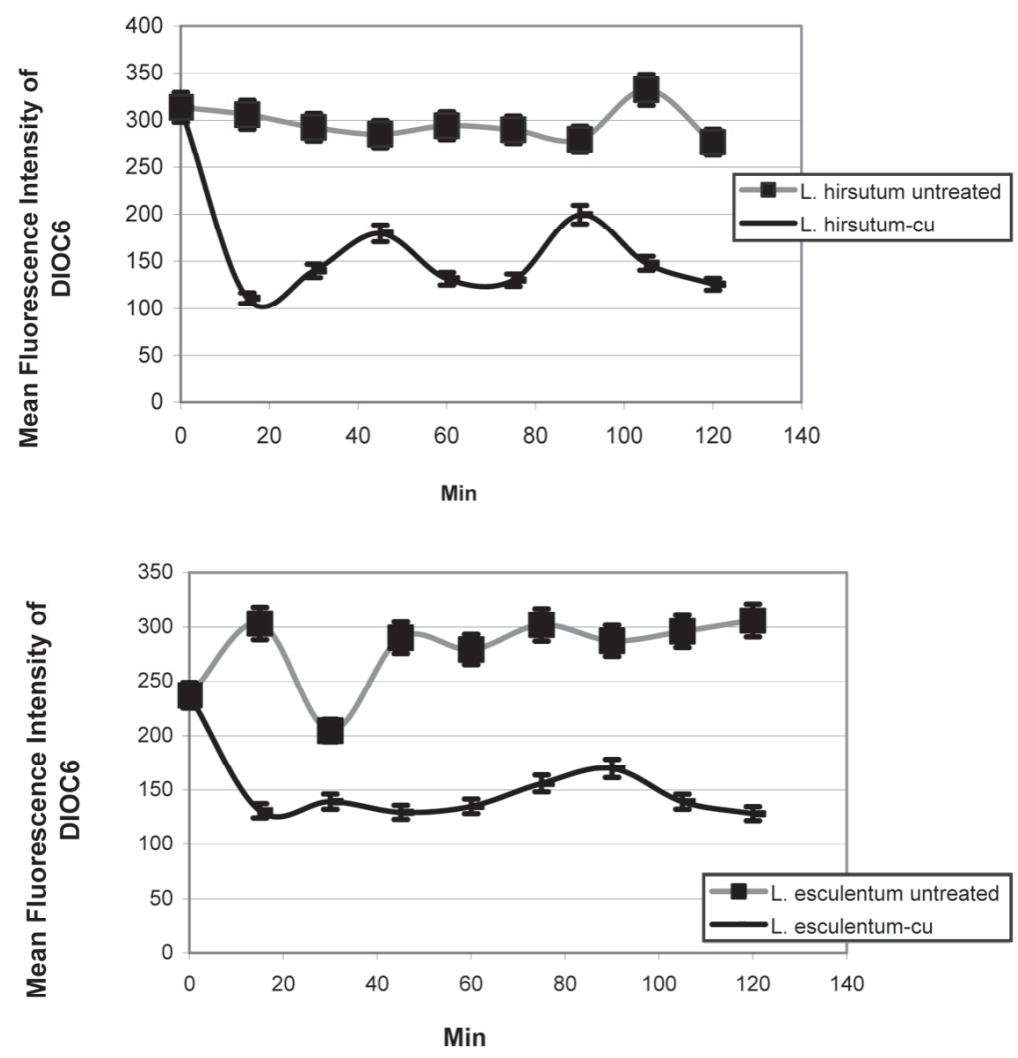

FIGURE 3 - Mean fluorescence intensity (MFI) of DiOC6 stain in protoplasts of $L$. hirsutum and L. esculentum during the first $2 \mathrm{~h}$ of treatment with $10 \mathrm{mM}$ $\mathrm{CuCl}_{2}$ compared to that in untreated control protoplasts.

TABLE 1 - Regression models for the mean fluorescence intensity (MF1) of protoplasts of Lycopersicon hirsutum and Lycopersicon esculentum during the first $2 \mathrm{~h}$ and $72 \mathrm{~h}$ of treatment with $10 \mathrm{mM} \mathrm{CuCl}_{2}$ and during $2 \mathrm{~h}$ of $1 \%$ paraquat treatment

\begin{tabular}{|c|c|c|}
\hline \multicolumn{3}{|c|}{ During $2 \mathrm{~h}$ of treatment with $10 \mathrm{mM} \mathrm{CuCl}{ }_{2}$} \\
\hline Treatment & Regression model & p-value \\
\hline L. hirsutum untreated & $\mathrm{MFI}=307.406-0.278262 * \mathrm{~min}$ & 0.002 \\
\hline L. hirsutum copper treatment & $\mathrm{MFI}=\operatorname{sqrt}(66454.5-5128.14 * \operatorname{sqrt}(\min ))$ & 0.05 \\
\hline L. esculentum untreated & $\mathrm{MFI}=\exp (5.5373+0.0168308 * \operatorname{sqrt}(\min )$ & 0.03 \\
\hline L. esculentum copper treatment & $\mathrm{MFI}=\operatorname{sqrt}(408168-238777 * \operatorname{sqrt}(\min ))$ & 005 \\
\hline \multicolumn{3}{|c|}{ During $72 \mathrm{~h}$ of treatment with $10 \mathrm{mM} \mathrm{CuCl}$} \\
\hline L. hirsutum untreated & $\mathrm{MFI}=\operatorname{sqrt}\left(99258.4-5335.55^{*} \operatorname{sqrt}(\right.$ hour $\left.)\right)$ & 0.55 \\
\hline L. hirsutum copper treatment & MFI- sqrt(8414.06 + 80345.8/hour) & 0.002 \\
\hline L. esculentum untreated & $\mathrm{M \Gamma I}=1 /(0.00334466 \mid 0.00454673 /$ hour $)$ & 0.25 \\
\hline L. esculentum copper treatment & MFI $=\operatorname{sqrt}\left(12981.7+7.39108 *\right.$ hour $\left.^{\wedge} 2\right)$ & 0.12 \\
\hline \multicolumn{3}{|c|}{ During $2 \mathrm{~h}$ of treatment with $1 \%$ paraquat } \\
\hline L. hirsutum untreated & $\mathrm{MFI}=307.406-0.278262 * \mathrm{~min}$ & 0.002 \\
\hline L. hirsutum paraquat treatment & $\mathrm{MFI}=391962+125267 * \min$ & 0.16 \\
\hline L. esculentum untreated & $\mathrm{MFI}=249607+0479333 * \min$ & 0.11 \\
\hline L. esculentum paraquat treatment & $\mathrm{MFI}=228.458+1.50978 * \min$ & 0.007 \\
\hline
\end{tabular}



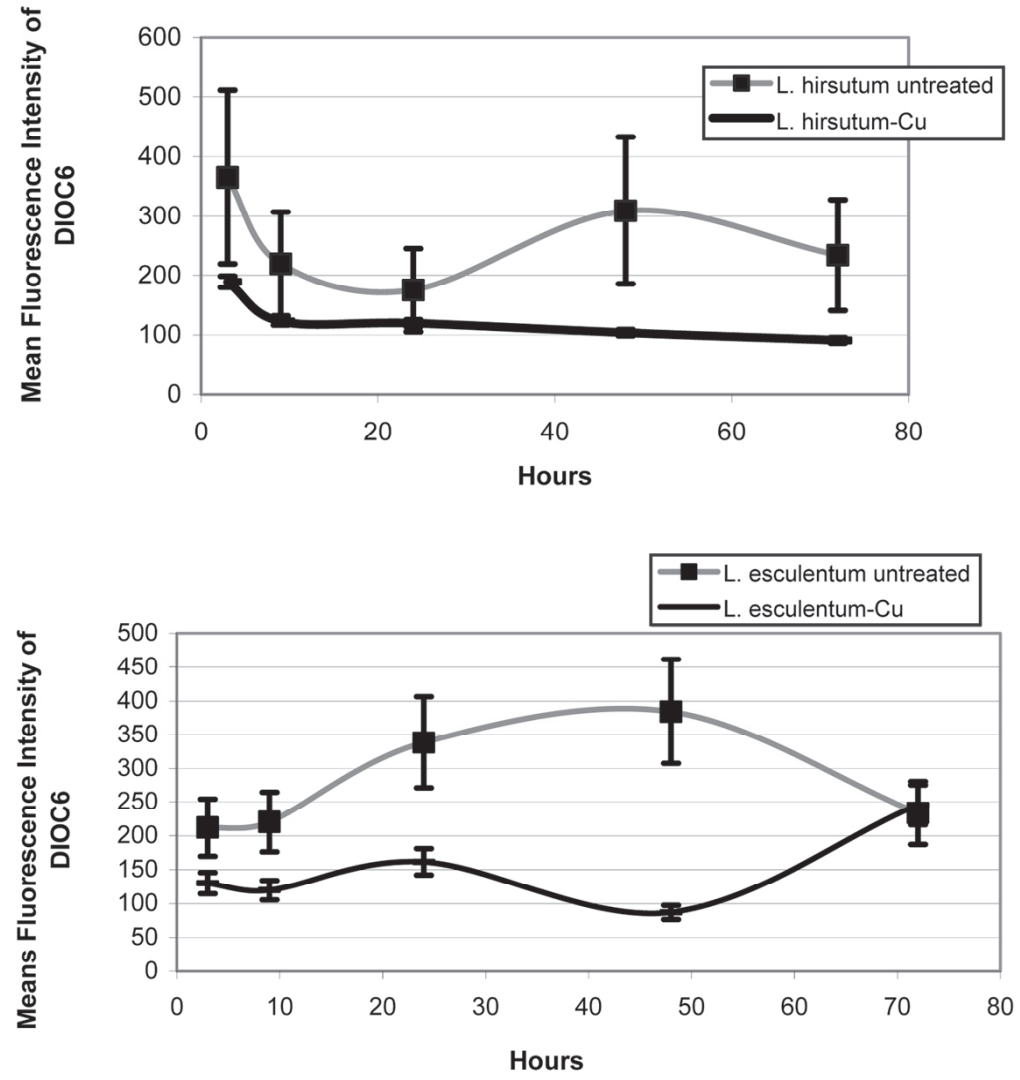

FIGURE 4 - Mean fluorescence intensity (MFI) of DiOC6 stain in protoplasts of $L$. hirsutum and $L$. esculentum during the first $72 \mathrm{~h}$ of treatment with $10 \mathrm{mM}$ $\mathrm{CuCl}_{2}$ compared to that in untreated control protoplasts.

lowest level of damage and the smallest slope occurred at the highest dosage of $10 \mathrm{mM} \mathrm{CuCl}_{2}$. There was no clear dose-response effect for mitochondrial damage because although there was an effect for the MFI, the depolarization or hyperpolarization effect as a function of concentration was unknown. As in the other experiments, the regression models for ROS production were generally not significant. In the dose-response assays for paraquat treatments, none of the models of the membrane damage variable were significant for either species. Mitochondrial damage was more clearly affected by paraquat dosage in L. hirsutum, which showed a gradient of hyperpolarization in accordance with increasing concentration. L. esculentum did not show a clear dose-response effect, but at $48 \mathrm{~h}$ the highest dosage showed the greatest degree of hyperpolarization. Dihydroethydine oxidation did not bring about a clear doseresponse effect; however, a significant production of these oxidative species was observed.

\section{DISCUSSION}

The literature has reported that the exposure of plants to heavy metals, specifically to copper, affects the photosystems and also provokes an oxidative explosion that leads to cell damage that is potentially irreversible (Hsu \& Lee, 1988; Narendranath et al., 1989; Yruela et al., 1996; Ke Shi-sheng, 2007). It should be noted that copper did not cause an oxidative burst as is normally suggested in other studies involving heavy metals in which the enzymatic activity associated with the Halliwell-Asada cycle has been evaluated (Gallego et al., 1996; Sang-Hoon et al., 2007; Akbulut \& Çakır, 2010). These results suggest that ROS do not play a role in copper-induced cell damage in the two species, either in direct damage or as molecules that participate in chemical signaling. These results differ from those found in other reports. However, due to experimental differences, it is not possible to directly compare the other studies to the present one.

Observations of the protoplasts of the two tomato species indicated that $10 \mathrm{mM} \mathrm{CuCl}$ quickly destabilized the electron transport chain on the mitochondria, but did not affect the integrity of the plasma membrane. All of the experiments, including the dose-response assays, revealed that the mitochondria were the main site of cell damage, an effect that was present in both species but that probably occurs more quickly in L. esculentum. The observed cell damage suggested a mechanism that may be associated with apoptosis. The results suggest that abiotic stresses that have 

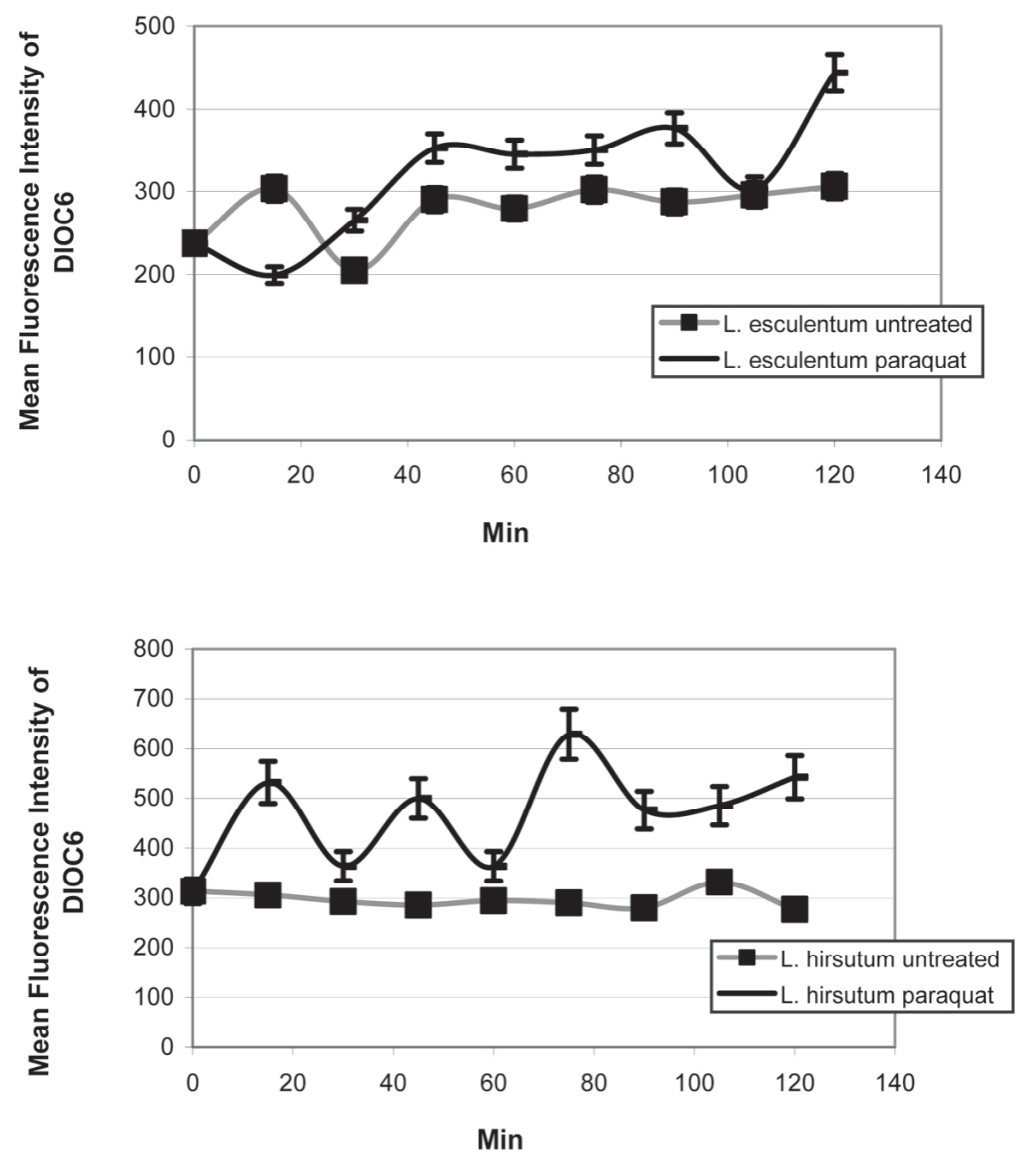

FIGURE 5 - Mean fluorescence intensity (MFI) of DiOC6 stain in protoplasts of L. hirsutum and L. esculentum during the first $2 \mathrm{~h}$ of treatment with $1 \%$ paraquat compared to that in untreated control protoplasts.

TABLE 2 - ROS production expressed as percentage of protoplasts with the presence of superoxide anion in L. hisutum and L. esculentum after the first $30 \mathrm{~min}$ of treatment with $1 \%$ paraquat

\begin{tabular}{lcc}
\hline \hline Treatment & $\begin{array}{c}\text { Percentage of protoplasts with ROS } \\
\text { presence }\end{array}$ & $\begin{array}{c}\text { Coefficient of } \\
\text { variation }\end{array}$ \\
\hline L. hirsutum untreated & 1.9 & 0.38 \\
L. hirsutum paraquat treatment & 32.9 & 2.18 \\
L. esculentum untreated & 2.0 & 0.57 \\
L. esculentum paraquat treatment & 25.4 & 2.18 \\
\hline
\end{tabular}

no co-evolutionary relationships can induce the expression of mechanisms closely linked to an immune response.

The results of the paraquat treatments confirm that oxidative stress begins as an early event, but is not exclusive to photosystem I. The mitochondria also undergo early-stage alteration, which makes sense considering the similarity between the electron transport chain systems of chloroplasts and mitochondria. The high dihydroethydine oxidation observed suggests that ROS production plays a role in cell death, not only during late events but also during early events, and is a possible initiator of destructive processes or a participator in chemical signaling.

The dose-response assays confirmed that at the concentrations used in this study, copper did not affect membrane integrity, but may have a membrane stabilizing effect in the protoplasts of L. hirsutum and L. esculentum. The ROS production experiments suggest that the effect of copper on the cell has nothing to do with membrane damage or the production of ROS, but rather it causes mitochondrial damage by destabilizing the internal mitochondrial membrane. Although an adequate dose-response relationship 
TABLE 3 - Membrane damage and production of reactive oxygen species in protoplasts of Lycopersicon hirsutum and Lycopersicon esculentum during $72 \mathrm{~h}$ of treatment with $1 \%$ paraquat

\begin{tabular}{llrrr}
\hline \hline Damage & Treatment & Intercept & Slope & \multicolumn{2}{c}{$\begin{array}{c}\text { p-value } \\
\text { Model } \mathbf{y}=\mathbf{a}+\mathbf{b x}\end{array}$} \\
& & & & 0.06 \\
& & 16.55 & 0.32 & 0.05 \\
Percentage of protoplasts with & L. hirsutum untreated & 942 & 084 & - \\
membrane damage & L. hirsutum-Paraquat & 3.95 & 0.55 & - \\
& L. esculentum untreated & -237 & 87 & 0.11 \\
& L. esculentum- Paraquat & & & 0.08 \\
Percentage of protoplasts with ROS & L. hirsutum untreated & 2718 & 031 & 0.32 \\
presence in the form of & L. hirsutum-Paraquat & 1465 & 1004 & 0.24 \\
superoxide anion & L. esculentum untreated & 6.7 & 0.05 & 0.5 \\
& L. esculentum- Paraquat & 38.5 & & \\
\end{tabular}
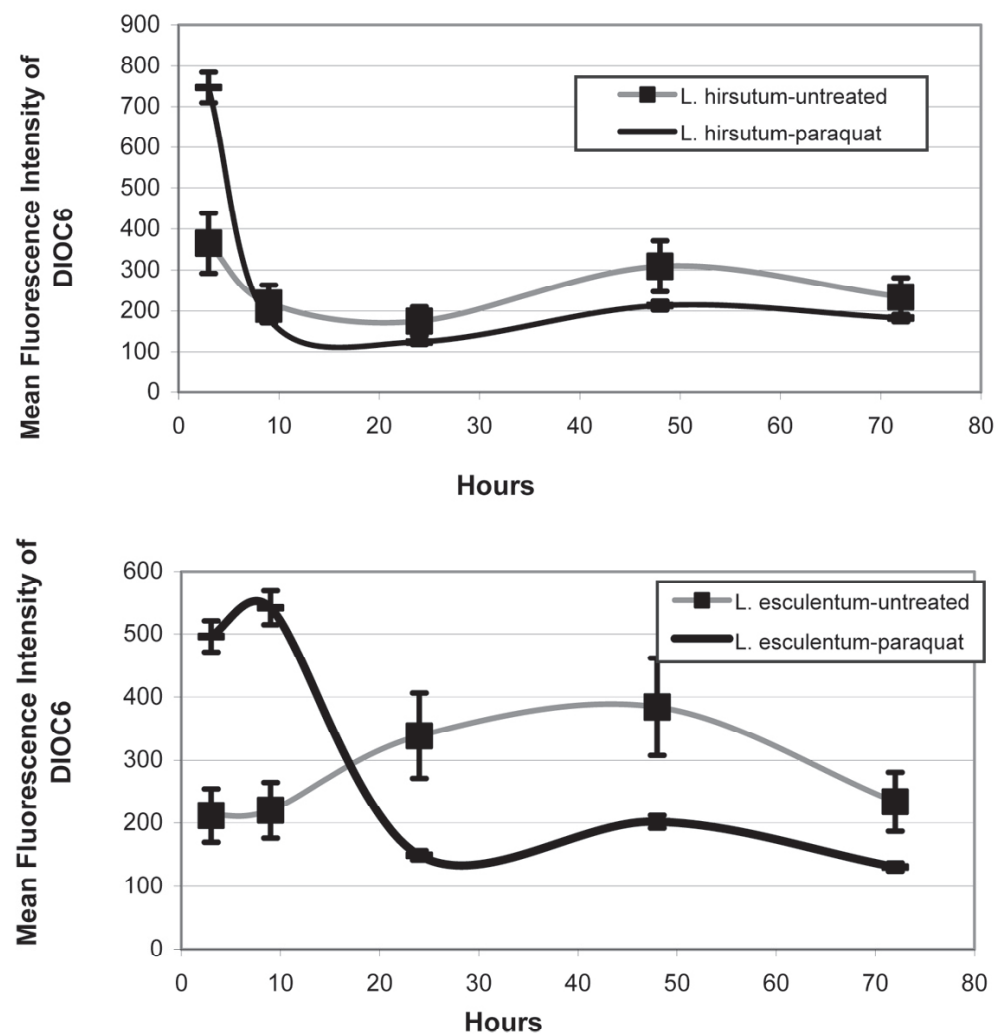

FIGURE 6 - Mean fluorescence intensity (MFI) of DiOC6 stain in protoplasts of L. hirsutum and L. esculentum during the $72 \mathrm{~h}$ of treatment with $1 \%$ paraquat compared to that in untreated control protoplasts.

could not be made for the paraquat treatments, significant membrane damage was observed. It is probable that the timing of the observations during the paraquat assays did not coincide with the initiation of membrane damage, and therefore a correlation with the dosage could not be made.

The tomato species used in this study exhibited differential behavior following the treatments. For example, the species $L$. hirsutum developed mitochondrial damage faster than $L$. esculentum during the copper treatment.
Moreover, a higher production of ROS and a greater change in mitochondrial membrane potential occurred as both early and late events during the paraquat treatment in L. hirsutum. These results showed that the two tomato species differed in their responses to copper and to paraquat. It would be interesting to do more studies targeted to evaluate the effect of stress induced by copper and Paraquat in tomato species on the differential expression of the hormonal balance (for example in the production of jasmonic acid, salicylic acid 
and other organic acids) and ROS production, and how that differential expression is related to the apoptosis process as a defense response.

\section{ACKNOWLEDGEMENTS}

The authors acknowledge CORPOICA for providing the genetic resources. They also thank Grupo Interdisciplinario de Estudios Moleculares (GIEM) of the Universidad de Antioquia for supporting this research and acknowledge Colciencias for its national $\mathrm{PhD}$ program support.

\section{REFERENCES}

Álvarez M, Espinosa F (2004) Jasmonatos y salicilatos: Fitohormonas clave en las reacciones de defensa de las plantas y de comunicación en el ecosistema. En: Reigosa MJ, Pedrol N, Sanchez A (Org.) La ecofisiología vegetal: una ciencias de síntesis. Madri. Thomson Editores.

Akbulut M, Çakır S (2010) The effects of Se phytotoxicity on the antioxidant systems of leaf tissues in barley (Hordeum vulgare L.) seedlings. Plant Physiology and Biochemistry 48:160-166.

Apel K, Hirt H (2004) Reactive oxygen species: metabolism, oxidative stress, and signal transduction. Annual Review of Plant Biology 55:373-99.

Breusegem F, Vranova E, Dat J, Inze D (2001) The role of active oxygen species in plant signal transduction. Plant Science 161:405-414.

Danon A, Delorme V, Mailhac N, Gallois P (2000) Plant programmed cell death: A common way to die. Plant Physiology and Biochemistry 38:647-655.

Fujita M, Fujita Y, Noutoshi Y, Takahashi F, Narusaka Y, Yamaguchi-Shinozaki K, Shinozaki K (2006) Crosstalk between abiotic and biotic stress responses: a current view from the points of convergence in the stress signaling networks. Current Opinion in Plant Biology 9:436-442.

Gallego S, Benavides MP, Tomaro ML (1996) Effect of heavy metal ion excess on sunflower leaves: evidence for involvement of oxidative stress. Plant Science 121:151-159.

Godbole A, Varghese J, Sarin, A, Mathew M (2003) VDAC is a conserved element of death pathways in plant and animal systems. Biochimica et Biophysica Acta 1642:87-96.

Hawley TS, Hawley RG (2004) Methods in Molecular Biology: Flow Cytometry Protocols. 2nd editoin. Totowa, NJ. Humana Press Inc.

Hofius D, Tsitsigiannis D, Jones J, Mundy J (2007) Inducible cell death in plant immunity. Seminars in Cancer Biology 17:166-187.

Hsu B, Lee J (1988) Toxic effects of copper on photosystem II of spinach chloroplasts. Plant Physiology 87:116-119.

Karp G (2006) Señalización celular y transducción de señales: comunicación entre células. En: Biología Celular y Molecular.
Cuarta edición. Mexico. McGraw Hill.

Ke S (2007) Effects of Copper on the photosynthesis and oxidative metabolism of Amaranthus tricolor seedlings. Agricultural Science in China 6:1182-1192.

Knight V, Wang H, Lincoln J, Lulai E, Gilchrist D, Bostock R (2001) Hydroperoxides of fatty acids induce programmed cell death in tomato protoplast. Physiological and Molecular Plant Pathology 59:277-86.

Lam E, Pontier D, Del Pozo O (1999) Die and let live-programmed cell death in plants. Current Opinion in Plant Biology 2:502-507.

Lamb C, Dixon RA (2004) The oxidative burst in disease resistance. Annual Review of Plant Physiology 65:31-38.

Lin J, Wang Y, Wang G (2006) Salt stress-induced programmed cell death in tobacco protoplasts is mediated by reactive oxygen species and mitochondrial permeability transition pore status. Journal of Plant Physiology 163:731-739.

Mithofer A, Schulze B, Boland W (2004) Biotic and heavy metal stress response in plants: evidence for common signals. Federation of European Biochemical Societies Letters 566:1-5.

Narendranath M, Imre V, Sandor D (1989) Copper toxicity affects photosystem II electron transport at the secondary quinone acceptor, QB1. Plant Physiology 90:175-179.

Pennell R, Lamb C (1997) Programmed cell death in plants. Plant Cell 9:1157-1168.

Tan M, Boerrigter H, Kool A (1987) A Rapid procedure for plant regeneration from protoplasts isolated from suspension cultures and leaf mesophyll cells of wild Lycopersicon species and Lycopersicon pennellii. Plant Science 49:63-72.

Sang-Hoon L, Nagib A, Ki-Won L, Do-Hyun K, Dong-Gi L, Sang-Soo K, Suk-Yoon K, Tae-Hwan K, Byung-Hyun L (2007) Simultaneous overexpression of both $\mathrm{CuZn}$ superoxide dismutase and ascorbate peroxidase in transgenic tall fescue plants confers increased tolerance to a wide range of abiotic stresses. Journal of Plant Physiology 164:1626-1638.

Torres MA, Dangl J (2005) Functions of the respiratory burst oxidase in biotic interactions, abiotic stress and development. Current Opinion in Plant Biology 8:397-403.

Van Doorn W (2005) Plant programmed cell death and the point of no return. Trends in Plant Science 10:478-483.

Vallejo FA (1999) Mejoramiento Genético y Producción de Tomate en Colombia. Palmira. Universidad Nacional de Colombia. Feriva 13:216.

Yakimova E, Kapchina-Toteva V, Woltering E (2007) Signal transduction events in aluminum-induced cell death in tomato suspension cells. Journal of Plant Physiology 164:702-708.

Yruela I, Puedo J, Alonso P, Picores R (1996) Photoinhibition of photosystem II from higher plants: effect of copper inhibition. The Journal of Biological Chemistry 271:27408-27415.

Zhang Z, Wang Y, Li J, Ji R, Shen G, Wang S, Zhou X, Zheng X (2004) The role of SA in the hypersensitive response and systemic acquired resistance induced by elicitor PB90 from Phytophthora boehmeriae. Physiological and Molecular Plant Pathology 65:31-38.

TPP 158 - Received 11 August 2010 - Accepted 1 February 2011 Section Editor: John C. Sutton 